\title{
Late-Onset Alzheimer's Disease Genes and the Potentially Implicated Pathways
}

\author{
Samantha L. Rosenthal $\cdot$ M. Ilyas Kamboh
}

Published online: 22 March 2014

(C) The Author(s) 2014. This article is published with open access at Springerlink.com

\begin{abstract}
Late-onset Alzheimer's disease (LOAD) is a devastating neurodegenerative disease with no effective treatment or cure. In addition to $A P O E$, recent large genome-wide association studies have identified variation in over 20 loci that contribute to disease risk: $C R I, B I N 1$, INPP5D, MEF2C, TREM2, CD2AP, HLA-DRB1/HLADRB5, EPHA1, NME8, ZCWPW1, CLU, PTK2B, PICALM, SORL1, CELF1, MS4A4/MS4A6E, SLC24A4/RIN3,FERMT2, CD33, ABCA7, CASS4. In addition, rare variants associated with LOAD have also been identified in $A P P$, TREM 2 and PLD3 genes. Previous research has identified inflammatory response, lipid metabolism and homeostasis, and endocytosis as the likely modes through which these gene products participate in Alzheimer's disease. Despite the clustering of these genes across a few common pathways, many of their roles in disease pathogenesis have yet to be determined. In this review, we examine both general and postulated disease functions of these genes and consider a comprehensive view of their potential roles in LOAD risk.
\end{abstract}

Keywords Late-onset Alzheimer's disease - Genetics · Biological pathways

S. L. Rosenthal · M. I. Kamboh ( $\square)$

Department of Human Genetics, Graduate School of Public Health, University of Pittsburgh, Pittsburgh, PA 15261, USA

e-mail: kamboh@pitt.edu

M. I. Kamboh

Alzheimer's Disease Research Center, University of Pittsburgh, Pittsburgh, PA, USA

\section{Introduction}

Alzheimer's disease (AD) is the sixth leading cause of death in the US. Healthcare costs in 2013 alone surpassed $\$ 200$ billion (USD), and this figure is estimated to be over 1 trillion dollars by 2050 [www.alz.org]. AD is characterized by two pathological hallmarks in affected areas of the brain, extracellular deposition of senile plaques and intracellular occurrence of neurofibrillary tangles (NFTs), produced by abnormal aggregation of amyloid beta $(A \beta)$ and hyperphosphorylation of tau, respectively. These plaques and tangles interfere with calcium signaling and synaptic transmission, induce a constant state of inflammation in the brain and ultimately lead to neuronal death. Patients with AD often initially present with mild cognitive impairment (MCI), which progresses to more severe memory loss and eventually loss of autonomy.

Alzheimer's disease is a complex and multifactorial neurodegenerative disease and a leading cause of dementia among elderly people. However, a small number of individuals develop $\mathrm{AD}$ at a younger age, and because of this variation in age at onset, the disease is classified into early ( $<60$ years age) and late ( $\geq 60$ years age) onset forms. Early onset Alzheimer's disease (EOAD) accounts for only $1-2 \%$ of all $\mathrm{AD}$ cases, and it usually follows an autosomal dominant inheritance pattern where mutations in a single gene can cause the disease. To date, mutations in three genes, including amyloid precursor protein $(A P P)$, presenilin $(P S)-1$ and $P S-2$, have been linked to EOAD [1-4].

Late-onset Alzheimer's disease (LOAD) is much more common and far more complex than EOAD with the possible involvement of multiple genes and gene-gene and geneenvironment interactions. Until 2009, APOE was the only established susceptibility marker for LOAD that accounts for $\sim 25$ of the estimated heritability of $\sim 80 \%$ [5]. This indicates the involvement of additional genetic factors that can 
modify the risk of LOAD. In order to identify the remaining genes for LOAD, efforts were focused on conducting genome-wide association studies (GWAS) because this approach is hypothesis free and conceptually would identify all known and unknown genes. However, with the exception of the $A P O E$ region, no other significant associations were replicated in earlier GWAS, indicating that the effect sizes of the remaining LOAD genes are small, and an exceptionally large number of cases and controls are required to identify additional genes. Since 2009, five large GWAS and a metaanalysis have identified significant associations of LOAD with SNPs in 20 additional loci, including $C L U, C R 1, P I-$ CALM, BIN1, ABCA7, MS4A4, EPHA1, CD2AP CD33, INPP5D, MEF2C, HLA-DRB1/HLA-DRB5, NME8, ZCWPW1, PTK2B, SORL1, CELF1,SLC24A4/RIN3,FER-

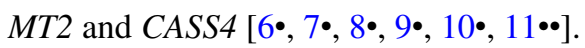

Generally, these genes fall into at least one of three pathways-inflammatory, lipid metabolism and endocytosisall of which have been suggested to play some role in disease. In addition to these genes where common variants are associated with disease risk, recent studies have identified rare variants in $A P P[12 \cdot]$, triggering receptor expressed on myeloid cells 2 (TREM2) [13•, 14•] and phospholipase D3 (PLD3) [15•] that also confer protection or risk against LOAD. Taken together, these findings produce a list of 24 genes/loci (Table 1), spread across the genome and loosely falling into the three common pathways, which mediate risk for LOAD. Below, we summarize the biology of each gene, postulate potential pathological mechanisms based upon their shared functions and regulatory networks, and suggest knowledge gaps that future studies may aim to fill.

\section{APOE (Apolipoprotein E)}

The association between the $A P O E$ genotype and $\mathrm{AD}$ risk is the strongest and best replicated association for any $\mathrm{AD}$ risk locus where the $A P O E^{*} 4$ is a risk allele and $A P O E^{*} 2$ is a protective allele. Its association with LOAD risk was determined prior to and validated with genome-wide association studies. Some of the most attractive theories for the role of $A P O E$ in $\mathrm{AD}$ pathogenesis involve its roles in inflammatory response, oxidative stress and lipid levels [16]. Interestingly, research has shown that both the $A P O E^{*} 2$ and $A P O E^{*} 4$ alleles increase the risk of cerebral amyloid angiopathy (CAA) by encouraging accumulation of $A \beta$ in the cerebral vasculature [17].

\section{Identification of LOAD Genes by Genome-wide Association Studies}

In addition to the established association of $A P O E$, recent GWAS have identified 20 genes/loci for LOAD. Below, we
Table 1 Late-onset Alzheimer's disease (LOAD) genes

\begin{tabular}{ll}
\hline Chromosome position & Gene \\
\hline $1 \mathrm{q} 32$ & $C R 1$ \\
$2 \mathrm{q} 14$ & BIN1 \\
$2 \mathrm{q} 37.1$ & INPP5D \\
$5 \mathrm{q} 14.3$ & MEF2C \\
$6 \mathrm{p} 12$ & CD2AP \\
$6 \mathrm{p} 21.1$ & TREM2 ${ }^{\mathrm{a}}$ \\
$6 \mathrm{p} 21.3$ & HLA-DRB5/HLA-DRB1 \\
$7 \mathrm{p} 14.1$ & NME8 \\
$7 \mathrm{q} 22.1$ & ZCWPW1 \\
$7 \mathrm{q} 34$ & EPHA1 \\
$8 \mathrm{p} 21.1$ & PTK2B \\
$8 \mathrm{p} 21-\mathrm{p} 12$ & $C L U$ \\
$11 \mathrm{p} 11$ & $C E L F 1$ \\
$11 \mathrm{q} 12.1$ & MS4A6A \\
$11 \mathrm{q} 14$ & PICALM \\
$11 \mathrm{q} 23.2-\mathrm{q} 24.2$ & SORL1 \\
$14 \mathrm{q} 22.1$ & FERMT2 \\
$14 \mathrm{q} 32.12$ & SLC24A4/RIN3 \\
$19 \mathrm{p} 13.3$ & ABCA7 \\
$19 \mathrm{q} 13.2$ & PLD $3^{\mathrm{a}}$ \\
$19 \mathrm{q} 13.2$ & APOE \\
$19 \mathrm{q} 13.3$ & $C D 33$ \\
$20 \mathrm{q} 13.31$ & $C A S S 4$ \\
$21 \mathrm{q} 21.3$ & APP \\
\hline & \\
\hline
\end{tabular}

${ }^{a}$ Rare variants in these genes are associated with LOAD risk

briefly discuss the known functions of the newly identified genes that might be relevant to AD biology. Since the GWAS approach generally identifies a genomic region associated with the disease and not necessarily the actual gene when there are multiple genes in a region, some of these genes should be considered provisional until confirmed by more in-depth functional tools.

\section{CR1 (Complement Component (3b/4b) Receptor 1)}

$\mathrm{CR} 1$ is a major player in the immune system. It serves as a B cell receptor for fragments of complement components $\mathrm{C} 3$ and $\mathrm{C} 4$ and is involved in factor-I mediated cleavage of $\mathrm{C} 3$, and thus regulates complement activation $[18,19]$. The exact relationship between CR1 function and LOAD is still unclear $[20,21]$. Evidence for a role in brain vasculature as a means to mediate LOAD risk has been provided by Holton et al. [22], who were able to detect low CRI expression in white matter and cerebellum. Individuals with the genotype pattern PICALM-GG, CRI-GG, APOE*4 had decreased episodic memory, an endophenotype of LOAD, regardless of their affection status, providing further evidence of CRl's role in LOAD risk [23]. 
BIN1 (Bridging Integrator 1)

BIN1 is a tumor suppressor gene that has been shown to be involved in a number of cancers, including hepatocellular carcinoma [24], melanoma [25], astrocytoma [26] and breast cancer [27]. Its known role in endocytosis [28] coupled with its association with LOAD makes it an attractive candidate gene for $\mathrm{AD}$. In one study of sporadic $\mathrm{AD}, \mathrm{BIN} 1$ protein levels were significantly lower in tissues from cases than from those of age-matched controls and neither overexpression nor knockdown of BINI affected APP processing in SH-SY5Y cells [29]. This study, which found no effect of BINI on tau pathology, differs from another by Chapuis et al. [30], which found BIN1 was increased in AD cases compared to controls and that the Drosophila ortholog to BINI, Amph, mediates Tau-induced neurotoxicity. The role of BINI in LOAD pathogenesis is still unclear and has been reviewed extensively by Tan et al. [31].

INPP5D (Inositol Polyphosphate-5-Phosphatase, $145 \mathrm{kDa}$, aka SHIP1)

INPP5D plays a role in a number of inflammatory responses in addition to its regulation of cytokine signaling and inhibition of the PI3K-driven oncogenic pathway [32, 33]. Differential expression for this gene has been observed between classical Hodgkin's lymphoma (cHL) cells and nodular lymphocyte predominant HL (nLPHL) cells, with the Hodgkin Reed-Sternberg cells of cHL showing decreased expression [34]. Furthermore, its expression has been shown to inhibit proliferation of acute myeloid leukemia cells [32]. Jickling et al. [35] have linked an increase in blood INPP5D with an increased risk of hemorrhagic transformation (HT) in ischemic stroke patients. HT is associated with increased blood-brain barrier permeability and thus may share some molecular mechanisms with AD. Of note is the binding of INPP5D with the product of another LOAD risk gene, $C D 2 A P$, in plasmacytoid dendritic cells (pDCs). This complex controls degradation of IgE receptor FceRI $\gamma$ [36]. As we discuss later in this review, some IgE receptors are members of the MS4A gene superfamily that has been associated with LOAD risk, indicating this complex and related pathways might be of importance to $\mathrm{AD}$ pathogenesis.

\section{MEF2C (Myocyte Enhancer Factor 2C)}

Previously, MEF2C mutations have been correlated with distinct phenotypes, specifically that of del5q14 syndrome, which is similar to Rett syndrome and characterized by seizures, severe mental retardations and stereotypical movements [37, 38]. Sakai et al. [39] reported the first case of del5q14 syndrome in a Japanese adolescent male who exhibited a neuroendocrine phenotype and hypothalamic defects. Interestingly, the Drosophila ortholog of MEF2C, $M e f 2$, has been shown to affect circadian behaviors and neuronal remodeling [40]. Since a number of AD patients experience disturbances in their circadian rhythms [41], it is possible that the association of $M E F 2 C$ is reflective of this secondary phenotype of $\mathrm{AD}$ rather than pathogenesis itself.

\section{CD2AP (CD2-Associated Protein)}

First identified as an adaptor protein with three Srchomology 3 (SH3) domains, CD2AP binds and clusters $\mathrm{CD} 2$ to facilitate junction formation between $\mathrm{T}$ cells and antigen-presenting cells [42]. Its role in endocytosis has been described, and its complex with cortactin links it to the cytoskeleton and vesicle movement [43]. This function makes $C D 2 A P$ a prime candidate for modulating $A \beta$ clearance. Increased susceptibility to neuritic plaque burden has been linked to $C D 2 A P$ variation [44]. $C D 2 A P$ behaves similarly to CIN85 (aka SH3KBPl) [43], the homologs of which have been identified as suppressors of A $\beta$ toxicity in yeast and C. elegans [45]. Similarly, another study in Drosophila found that loss of the fly ortholog of $C D 2 A P$ and $C I N 85$, cindr, increased tau neurotoxicity in transgenic flies, further suggesting CD2AP normally functions in a protective role against AD risk [46].

HLA-DRB1/HLA-DRB5 (Major Histocompatibility Complex, Class II, DR Beta 1/Major Histocompatibility Complex, Class II, DR Beta 5)

The HLA-DRB1/HLA-DRB5 locus is a member of the major histocompatibility complex, a highly polymorphic region located on chromosome 6 that is responsible for numerous immune responses [47]. GWA studies have associated this locus with both multiple sclerosis [48] and another proteinopathy, Parkinson's disease (PD) [49, 50]. Remarkably, knockout of MHCII in mice protects against $\alpha$-synuclein-induced neurodegeneration, which is characteristic of PD [51]. While Parkinson's and Alzheimer's are two distinctly different diseases, both are characterized by neurodegeneration resulting from abnormal protein aggregation. Given the association of this locus with LOAD and the demonstration that MHCII signaling activates microglia in Parkinson's [51], HLA-DRB1/HLA-DRB5 may have a similar role in inflammatory responses that contribute to both pathologies.

\section{EPHA1 (EPH Receptor A1)}

The EPHA1 receptor is a member of protein tyrosine receptors. There is high affinity for the receptor with its 
membrane-bound ligand, ephrin-A1. The interaction between EPHA receptors and ephrins is thought to play a role in synapse formation and development [52] and to regulate $\mathrm{T}$ cell interactions through integrin pathway [53]. Expression of EPHAl occurs in lymphocytes and epithelial cells and is downregulated in lipopolysaccaharide (LPS) fever-induced inflammation in rats [54]. A study of MCI individuals compared to healthy controls identified an association between $\mathrm{A} \beta$ deposition and EPHA1 expression, with the $C$ allele of rs11767557 being associated with decreased risk of being $A \beta$-positive. This association was only found in cognitively normal individuals, not those with MCI [55]. Overexpression of EPHAl also has been reported to produce more aggressive tumors in ovarian cancer [56].

\section{NME8 (NME/NM23 Family Member 8)}

Defects in NME8 (aka TXNDC3) have been associated with primary ciliary dyskinesia [57], and variation in this gene has been linked to increased bone mineral density and knee osteoarthritis risk [58, 59]. Work in mice has shown that deletion of the thioredoxin domains in sperm increases their age-related susceptibility to oxidative stress-induced phenotypes [60]. Literature on this gene is limited and indicates expression is primarily restricted to testis and respiratory epithelial cells [60, 61]. However, if expression of $N M E 8$ was observed in the brain, the association between NME8 and AD risk could be explained by variation that modifies its antioxidant action and subsequently alters the level of oxidative stress. Alternatively, variation in NME8 could serve as an eQTL (expression quantitative trait loci) for other gene(s) whose expression is directly relevant to AD risk.

\section{ZCWPW1 (Zinc Finger, CW Type with PWWP Domain 1)}

To date, only one paper has been published on ZCWPWI. He et al. [62] used solution NMR spectroscopy in the first and only determination of the 3D structure of ZCWPW1. This protein contains zf-CW domain, which has been identified in a number of other proteins responsible for chromatin remodeling and methylation states. The PWWP domain is also present in ZCWPW1 and, similar to the zf$\mathrm{CW}$ domain, has been described in epigenetic regulations, indicating $Z C W P W 1$ as a histone modification reader [62]. Recently, a variant in ZCWPWI (rs1476679) associated with LOAD risk was also found to have functional relevance (RegulomeDB score: $1 \mathrm{f}$ ), as it serves as an eQTL for GATS, PILRB and TRIM4 and affects binding of CTCF and RFX3 [Rosenthal, unpublished data].

\section{CLU (Clusterin)}

CLU, also referred to as apolipoprotein J (APOJ), has been implicated in the formation of complexes that can cross the blood-brain barrier [63]. It is one of the primary chaperones for removal of $A \beta$ from the brain [64]. AD patients have increased levels of CLU in the cortex and hippocampus $[65,66]$, so a link between increased levels of CLU and AD risk [67] is both expected and observed. Related to this, Thambisetty et al. [68] found an association between increased plasma clusterin and hippocampal atrophy, as well as disease severity and progression, suggesting its potential utility as a biomarker. In contrast, other studies show that the minor allele of the associated SNP, CLU/ rs11136000, is associated with increased $C L U$ expression but decreased AD risk, further complicating the relationship between CLU and Alzheimer's disease [6•, 7•, 69, 70]. One possibility proposed by Ling et al. [69] is that for the increase in $C L U$ expression to reduce risk, it must occur over the lifespan, prior to disease onset. In addition to its role in neurodegeneration, $C L U$ expression affects chemotherapy resistance and severity of some cancers, which may be indicative of an inflammatory mechanism of action in $\mathrm{AD}$, in addition to lipid trafficking [71-74]. Clusterin's role in $\mathrm{AD}$ pathogenesis has been reviewed in depth by Nuutinen [64].

\section{PTK2B (Protein Tyrosine Kinase 2 Beta)}

The $P T K 2 B$ gene is located on chromosome 8 near the $C L U$ gene. We originally reported that $P T K 2 B$ was a potential new risk gene for $\mathrm{AD}$, as we found multiple significant signals (albeit not genome-wide significant) in the $P T K 2 B$ gene [75]. This observation has now been confirmed by the meta-analysis where $P T K 2 B$ has been identified as a genome-wide significant locus for LOAD [11••]. PTK2B, also called PYK2, is a member of the focal adhesion kinase (FAK) family, a non-receptor protein tyrosine kinase family [76]. It responds to a number of stimuli and is subsequently activated by these stimuli through a combination of autophosphorylation and phosphorylation by Src-family kinases [77]. One such stimulus for $P T K 2 B$ activation is changes in intracellular calcium levels, which are disrupted in AD brains [76, 78]. PTK2B indirectly regulates N-methyl-D-aspartate receptor (NMDAR) activity through src kinases [79, 80]. Work in mice suggests that loss of protein tyrosine phosphatase alpha (PTP- $\alpha$ ), a regulator of $P T K 2 B$, can cause defects in NMDAR processes, including memory [81]. 
MS4A4A/MS4A6E (Membrane-Spanning 4-Domains, Subfamily A, Member 4A/Membrane-Spanning 4-Domains, Subfamily A, Member 6E)

Perhaps the most interesting AD risk locus is the $M S 4 A$ region located on chromosome 11 . Despite its continued replication in multiple GWAS and original characterization over a decade ago, little else has been determined about this gene family $[82,83]$. Members of the $M S 4 A$ family of proteins have four transmembrane domains and are diversely expressed [82, 83]. Similarities between the structure and expression of mouse and human HTm4 (MS4A3), another member of the $M S 4 A$ family, have been demonstrated. Of interest is the expression of HTm4 in the developing central nervous system of mice [84]. Expression of MS4A6A has been shown to correlate with Braak tangle and Braak plaque scores in AD patients, as was the minor allele $M S 4 A 6 E /$ rs670139 [85]. Allen et al. [70] have identified variations in proxies of the genome-wide significant SNP rs670139 that increase MS4A4A's expression in the brain and subsequently increase disease risk. Given the consistent replication of these loci with $\mathrm{AD}$ risk, it is essential that this gene family be studied with more functional techniques to assess its role in both normal and disease states.

PICALM (Phosphatidylinositol Binding Clathrin Assembly Protein)

APP trafficking as well as A $\beta$ clearance, specifically via clathrin-mediated endocytosis (CME), is one of the proposed pathways for affecting LOAD risk. Work in yeast and $C$. elegans has shown homologs of PICALM to be suppressors of A $\beta$ toxicity [45]. More recently, Ando et al. [86] identified a link between PICALM and characteristic tau pathology of AD brains, specifically co-localization of PICALM with tau in NFTs, but not with pre-tangles or extracellular ghost tangles. Alternative splicing of PICALM yields three isoforms, and post-mortem studies of brain samples revealed a decrease in the levels of full-length PICALM and an increase in the shorter species in cases, indicating abnormal proteolysis of PICALM may affect A $\beta$ clearance although no interaction between PICALM and $\mathrm{A} \beta$ was observed.

SORL1 [Sortilin-Related Receptor, L(DLR class)

A Repeats Containing]

Nearly a decade ago, Scherzer et al. [87] identified a link between decreased SORL1 (LR11) expression and AD. Microarray analysis of lymphoblast DNA showed a clear downregulation of SORL1 expression in AD patients, and immunohistochemistry of AD brains exhibited decreased staining of pyramidal neurons and lowered protein levels in the frontal cortex. Additionally, single-site and haplotype association of SORL1 with risk of amnestic mild cognitive impairment (aMCI), a common precursor to $\mathrm{AD}$, has been reported in the Han Chinese [88]. Glerup et al. [89] have demonstrated SORL1 as an endocytic modulator of glialderived neurotrophic factor (GDNF) and its related receptor, GFR $\alpha 1$.

\section{CELF1 (CUGBP, Elav-like Family Member 1)}

CELF1 is largely implicated in myotonic dystrophy type I (DMI) because of its interaction with DMPK [90, 91]. However, Kim et al. [92] have shown that elimination of CELF1 in transgenic mice with induced RNA toxicity does not completely alleviate features of DMI. CELF1 has also been associated with certain types of cancer. For example, Talwar et al. [93] have observed overexpression of CELF1 in oral squamous cancer cells results in a reduction of proapoptotic mRNA transcripts that ultimately leads to cell proliferation. The fly homolog of CELF1, aret, has been shown to mediate tau toxicity [46]. Recently, we have identified eight variants in linkage disequilibrium with the reported $C E L F 1 /$ rs10838725 that have suggestive functional relevance (RegulomeDB score: 1f) and are eQTLs for CIQTNF4. These data suggest that CELF1 may be acting in conjunction with or serving as a proxy for other genes in this region that mediate $\mathrm{AD}$ risk [Rosenthal, unpublished data].

\section{SLC24A4/RIN3 (Solute Carrier Family 24 (Sodium/} Potassium/Calcium Exchanger), Member 4/Ras and Rab Interactor 3)

SLC24A4 is a solute carrier that has been associated with pigmentation traits in European populations [94, 95]. Since SLC24A4 is involved in iris development, it may also be involved in neuronal development and thus contribute to AD risk [96]. Two variants in this gene have been identified in Pakistani families with amelogenesis imperfecta (AI), and Slc24a4 knockout mice have severe enamel defects, indicating a role for this solute carrier in amelogenesis [97]. Perhaps of most relevance to $\mathrm{AD}$ is the association of this gene with blood pressure in African Americans as AD may be influenced by vascular disease [98].

FERMT2 (Fermitin Family Member 2)

FERMT2 (aka kindlin-2, KIND2) is a member of the Fermitin family of proteins, which are involved in cellmatrix adhesion complexes. FERMT2 can stimulate genomic instability, which ultimately facilitates breast 
cancer progression, and it also has been identified as a binding partner for KIND1, mutations in which are responsible for Kindler syndrome [99, 100]. Shulman et al. [46] independently validated the recent association of FERMT2 with LOAD risk after performing a gene screen and in vivo studies in Drosophila melanogaster. Their work in flies shows altered expression of both FERMT2 and CELF1 homologs modulates Tau neurotoxicity as measured by a retinal phenotype and suggests biological relevance for these associations.

\section{ABCA7 [ATP-Binding Cassette, Sub-family}

\section{A (ABC1), Member 7]}

ABCA7 is a member of the ATP-binding cassette genes that are responsible for lipid transport, a particularly important function in the central nervous system [101]. Kim et al. [102-104] performed a number of mouse studies concerning the expression and function of $A B C A 7$. Loss of $A B C A 7$ is not embryonic lethal and does not produce any clear irregularities in young mice, which is consistent with the late age at onset of AD. Their work has demonstrated that knockout of $A B C A 7$ does not affect cholesterol efflux by macrophages, nor is it sufficient to compensate when function of homologous lipid transporter, $A B C A 1$, is lost. $A B C A 7$ expression is highest in the hippocampus, one of the earliest affected regions in the brains of $\mathrm{AD}$ patients, and microglia, the cells responsible for cerebral inflammatory response [102, 103]. ABCA7 also participates in macrophage uptake of $\mathrm{A} \beta$, and ablation of $A B C A 7$ results in increased levels of insoluble $A \beta$ [104]. ABCA7 also has been shown to mediate APP processing [105]. It remains to be seen whether the action of ABCA7 in AD is through its interaction with APOE and lipid metabolism, its function as an immune system molecule or a combination of both. $A B C A 7$ also has been associated with age at onset of $\mathrm{AD}$ [85]. A GWAS in African Americans found an effect size similar to $A P O E$ for $A B C A 7 / \mathrm{rs} 115550680$ (OR 2.31, $p=5.5 \times 10^{-47}$, OR $1.79, p=2.21 \times 10^{-9}$, respectively), highlighting the diversity of genetic effects on different genetic backgrounds [106].

\section{CD33 (CD33 Molecule)}

CD33 belongs to a class of immune cell surface receptors called sialic acid-binding immunoglobulin-like lectins (Siglecs). CD33 triggers immune cell-cell interactions through its own clathrin-independent endocytosis [107]. It has been shown that $C D 33$ expression is increased in AD brains [85], as is the number of CD33-positive microglia [108]. Both affected and asymptomatic carriers of the ' $C$ ' risk allele for the associated $C D 33 /$ rs3865444 variant have a higher probability of being positive for Pittsburgh
Compound B (PiB). Notably, carriers of ' $\mathrm{C}$ ' risk allele also have a higher likelihood of obtaining an $\mathrm{AD}$ diagnosis, but the effects of the risk allele appear to have no bearing on tangle formation and are thus limited to plaque pathology, likely due to its inhibition of $\mathrm{A} \beta 42$ uptake and clearance by microglia [108, 109].

\section{CASS4 (Cas Scaffolding Protein Family Member 4)}

CASS4 is a relatively understudied gene as evidenced by a mere three publications returned in a PubMed search for the gene and its alias, HEPL. The reported GWAS significant SNP, CASS4/rs7274581, is protective against AD, and a SNP in LD with this GWAS SNP, CASS4/rs6024870, shows evidence of regulatory function as well [Rosenthal, unpublished data]. CASS4 is a member of the CAS protein family, scaffolding proteins responsible for a number of cellular activities [110]. First characterized in 2008, CASS 4 shares up to $42 \%$ similarity in gene sequence with the other three members of the CASS family, but lacks the conserved YDYVHL motif. It is most highly expressed in spleen and lung tissues, as well as ovarian and leukemia cell lines, and its importance appears to be cell-specific and dependent upon the presence or absence other CAS family members' expression [111]. Dcas, the Drosophila homolog to CAS family proteins, interacts with integrin pathway genes during early embryogenesis [112], and Kirsch et al. [113] have also demonstrated an interaction between another CAS family member, CASS1, and an established AD locus, $C D 2 A P$.

\section{Identification of LOAD Genes by Genomic Sequencing}

In addition to $A P O E$, GWAS have made significant contribution in identifying 20 genes/loci for LOAD, but together common variants in these 21 genes explain about half of the estimated $\sim 80 \%$ heritability of $\mathrm{AD}$ [5]. This finding is consistent with published data for different diseases and traits where GWAS explain only a small fraction of the estimated genetic variance [114, 115], partly because GWAS arrays are designed to capture mainly the common variants with low penetrance and not the rare variants having higher individual penetrance. In the post-GWAS era, it is becoming necessary to perform genomic sequencing (targeted sequencing, whole exome-sequencing or whole-genome sequencing) in order to detect functional rare variants not only in known genes, but this approach will also help to identify new genes for LOAD. Recently, the application of whole-exome sequencing has resulted in the identification of rare functional variants in three additional genes for LOAD, including APP, TREM2 and PLD3. 
APP (Amyloid Precursor Protein)

The association between $A P P$ and $A D$ is well established for EOAD; however, it was not until recently that a link between APP and the common LOAD was reported. APP is sequentially cleaved by $\alpha$-secretase and then $\gamma$-secretase to produce amyloid intracellular domain and $\mathrm{C} 3$ fragments. Cleavage of APP by $\beta$-secretase rather than $\alpha$-secretase produces a longer version of the peptide that is prone to aggregation and results in the formation of $\mathrm{A} \beta$ plaques characteristic of $\mathrm{AD}$. A rare protective variant, A673T, has been identified in Icelandic and Finnish individuals with a strong effect size $[12,116]$. Thus far, it seems the link between this rare variant is restricted to members of these populations as other studies have not detected this variant in other populations $[117,118]$. However, these findings do suggest that APP may warrant a second look via sequencing to determine whether other rare variants in this gene exist that may explain some of the missing heritability for LOAD.

TREM2 (Triggering Receptor Expressed on Myeloid Cells 2)

TREM2 has only recently been added to the list of associated LOAD genes and stands out among the 24 identified loci because of a missense mutation that has a similar effect size to the $A P O E^{*} E 4$ allele. The rare $\mathrm{R} 47 \mathrm{H}$ variant was found in both the Icelandic [14.] population and an international cohort of European descent [13•]. A metaanalysis of these studies and others reports an odds ratio of 3.4 [119], further strengthening the case for TREM2 as a major LOAD risk locus. Previously, mutations in TREM2 have been associated with Nasu-Hakola disease (aka polycystic lipomembranous osteodysplasia with sclerosing leukoencephalopathy, PLOSL) $[120,121]$. This rare recessive disease counts progressive frontal-type dementia among its clinical features, which makes the association of TREM2 with LOAD interesting despite variations in age at onset and type of dementia [122]. The TREM2 receptor is expressed by microglia, and expression of its ligands, TREM2-L, is amplified in apoptotic neurons. Furthermore, inhibition of TREM2 activity decreases phagocytosis of these cells by approximately one third, suggesting the interaction between TREM2 and its ligands facilitates clearance of apoptotic neurons [123].

\section{PLD3 (Phospholipase D Family, Member 3)}

The latest addition to the list of AD risk loci is PLD3. Its role in LOAD risk was first identified in a small study of 14 families with the variant $P L D 3 /$ rs 145999145 and was validated in a population-based study as increasing LOAD risk $(\mathrm{OR}=2.10)$. This variant was also associated with age at onset [15•]. PLD3 is a signaling enzyme about which little has been described. Zhang et al. [124] have shown Akt phosphorylation is inhibited in myoblasts when PLD3 is overexpressed, and Osisami et al. [125] have suggested its role in myogenesis may be specifically related to myotube formation. Remarkably, another risk locus, $P T K 2 B$, has been shown to participate in a signaling pathway responsible for Akt activation [126]. $P L D 3$ also has been identified as a potential modifier of $B R C A 1$ and BRCA2 [127].

\section{Pathway Analysis}

Using Ingenuity Pathways Analysis software (version 18030641, Ingenuity Systems, Inc., 2014), we were able to assess the wide variety of shared functions of these loci. We examined a total of 27 molecules representing the GWAS loci (Table 2). Not surprisingly, the most significant of these function or disease annotations were LOAD $(p=2.88 \mathrm{E}-21)$ and $\mathrm{AD}(p=2.05 \mathrm{E}-15)$ with 9 and 14 molecules implicated, respectively (Table 3). After removing annotations with three or fewer molecules, we were left with a total of 36 nominally significant $(p<0.05)$ groups of genes across a number of categories and function annotations. Late-onset Alzheimer's disease and Alzheimer's disease remained the most significant, followed by engulfment of cells and leukocytes $(p=1.17 \mathrm{E}-06$, $p=1.68 \mathrm{E}-06$, respectively). Both of these annotations cite APOE, INPP5D, TREM2, ABCA7 and BINI as molecules involved in these processes, with CRI and PICALM included in the broader "engulfment of cells" annotation. The disease annotation with the most molecules involved is cancer, with 18 of the 27 genes involved ( $p=3.63 \mathrm{E}-03)$. Indeed, of the 36 groups of genes, 14 are related to cancer, immunity/immunological disease or inflammatory responses/inflammatory disease (Table 3).

$A B C A 7, B I N 1, I N P P 5 D$ and TREM2 are jointly implicated in three forms of phagocytosis, as well as immune response, suggesting they act in tandem to modify these specific aspects of AD. Similarly, APOE, CR1, INPP5D, PTK2B and TREM2 are jointly responsible for movement of phagocytes and myeloid cells, indicating another group of closely related genes whose activity affects the same cellular functions. Smaller groups of related molecules may better inform about the disease process than individual gene activities such that the whole phenotype attributed to genetic background is greater than the sum of its parts. 
Table 2 LOAD risk loci examined in IPA analysis

\begin{tabular}{|c|c|c|}
\hline Symbol & Entrez gene name & Location \\
\hline$A B C A 7$ & ATP-binding cassette, sub-family A (ABC1), member 7 & Plasma membrane \\
\hline$A P O E$ & Apolipoprotein E & Extracellular space \\
\hline BIN1 & Bridging integrator 1 & Nucleus \\
\hline CASS4 & Cas scaffolding protein family member 4 & Other \\
\hline$C D 2 A P$ & CD2-associated protein & Cytoplasm \\
\hline$C D 33$ & CD33 molecule & Plasma membrane \\
\hline CELF1 & CUGBP, Elav-like family member 1 & Nucleus \\
\hline$C L U$ & Clusterin & Cytoplasm \\
\hline CRI & Complement component (3b/4b) receptor 1 (Knops blood group) & Plasma membrane \\
\hline EPHAl & EPH receptor A1 & Plasma membrane \\
\hline FERMT2 & Fermitin family member 2 & Cytoplasm \\
\hline$H L A-D R B 1$ & Major histocompatibility complex, class II, DR beta 1 & Plasma membrane \\
\hline HLA-DRB5 & Major histocompatibility complex, class II, DR beta 5 & Plasma membrane \\
\hline INPP5D & Inositol polyphosphate-5-phosphatase, $145 \mathrm{kDa}$ & Cytoplasm \\
\hline$M E F 2 C$ & Myocyte enhancer factor $2 \mathrm{C}$ & Nucleus \\
\hline$M S 4 A 4 A$ & Membrane-spanning 4-domains, subfamily A, member 4A & Other \\
\hline$M S 4 A 4 E$ & Membrane-spanning 4-domains, subfamily A, member $4 \mathrm{E}$ & Other \\
\hline$M S 4 A 6 A$ & Membrane-spanning 4-domains, subfamily A, member 6A & Other \\
\hline$M S 4 A 6 E$ & Membrane-spanning 4-domains, subfamily A, member $6 \mathrm{E}$ & Other \\
\hline NME8 & NME/NM23 family member 8 & Cytoplasm \\
\hline PICALM & Phosphatidylinositol binding clathrin assembly protein & Cytoplasm \\
\hline$P T K 2 B$ & Protein tyrosine kinase 2 beta & Cytoplasm \\
\hline RIN3 & Ras and Rab interactor 3 & Cytoplasm \\
\hline SLC24A4 & Solute carrier family 24 (sodium/potassium/calcium exchanger), member 4 & Plasma membrane \\
\hline SORL1 & Sortilin-related receptor, L(DLR class) A repeats containing & Cytoplasm \\
\hline TREM2 & Triggering receptor expressed on myeloid cells 2 & Plasma membrane \\
\hline$Z C W P W 1$ & Zinc finger, CW type with PWWP domain 1 & Other \\
\hline
\end{tabular}

The overlap of molecules among different annotations is important as it suggests these genes do not act in isolation, but work in combination so that their actions with respect to disease risk and pathogenesis are dependent upon each other. For example, genetic variation in SORL1 may mediate an inflammatory mechanism when occurring alongside genetic variation in $P T K 2 B$, but may be more relevant to endocytosis when occurring with genetic variation in $C D 2 A P$. As disease mechanisms become clearer, it will be necessary to view disease risk as a function of multiple genetic variants and their interactions.

\section{Conclusion}

Upon review of the literature, it becomes apparent that the genetic mechanisms implicated in AD are incredibly varied and widely distributed across biological functions. The combination of these findings emphasizes the complexity of the disease and suggests multiple therapeutic targets. It will also be important to consider both genetic and environmental factors when attempting to determine major risk factors, as gene effect sizes may be modulated by external factors and vice versa. One particularly curious observation from this review is the number of genes identified by GWAS of LOAD that also have known roles in cancer risk, severity and therapy response. Additionally, incidence rates of cancer seem to be lower among those affected with AD compared to the general population, and the same can be said of cancer survivors with respect to $\mathrm{AD}$ incidence [128]. Ganguli [129] comments on this seemingly inverse relationship between cancer and $\mathrm{AD}$. Given our results from the pathway analysis, this supposed relationship warrants a more deliberate focus in future studies to accurately assess its legitimacy. 


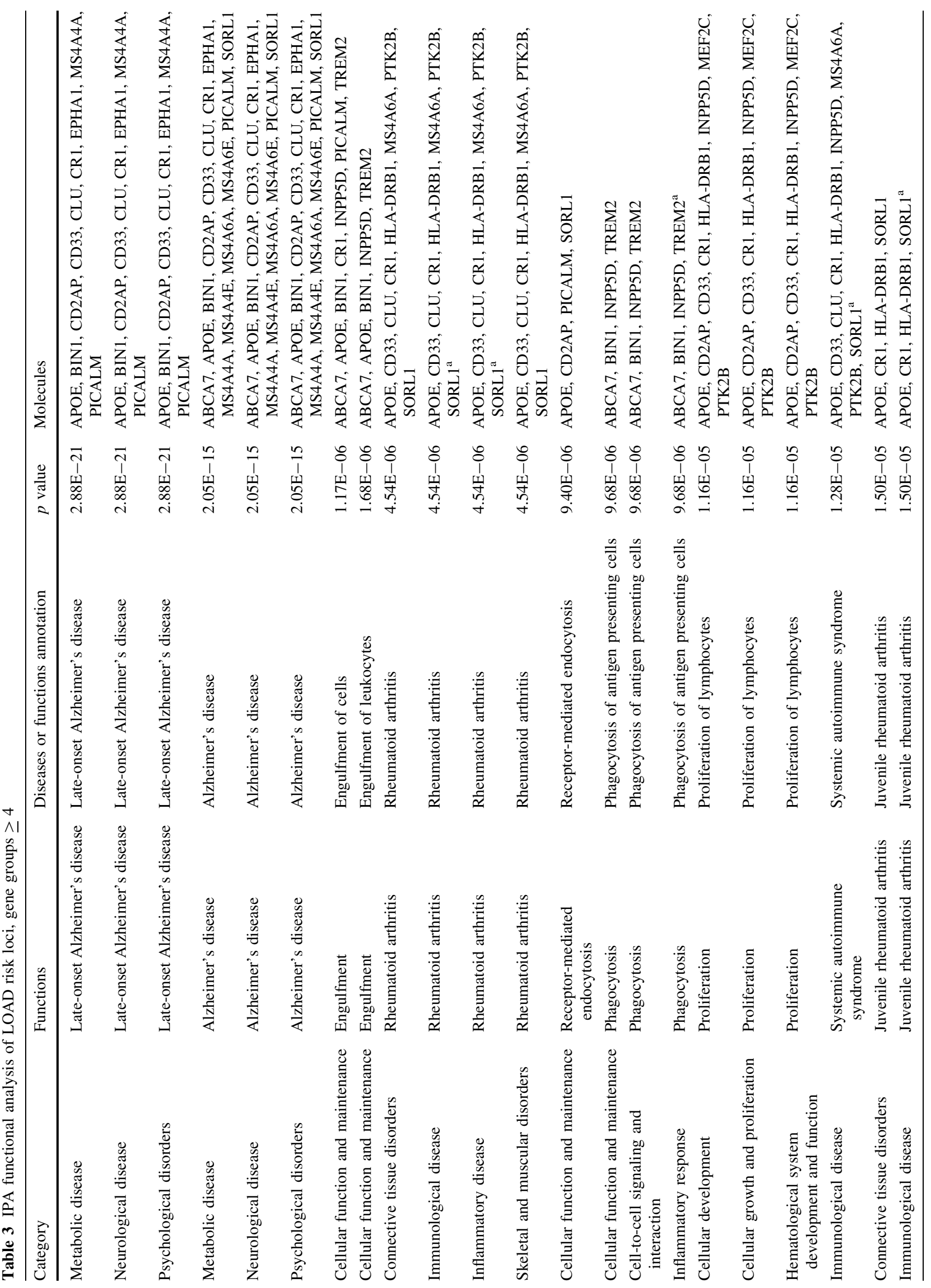


艺育

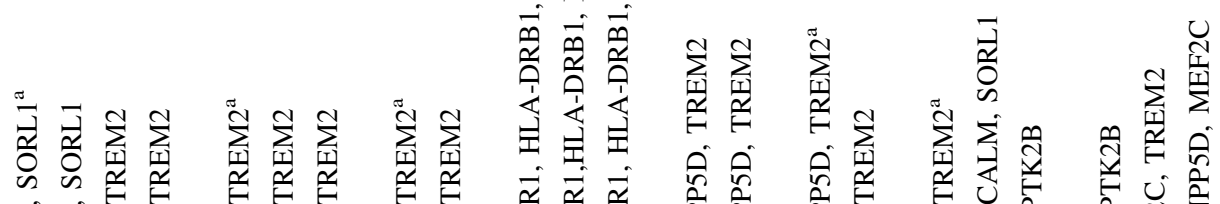

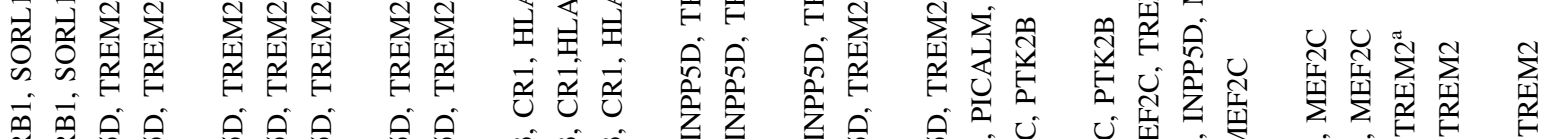

की

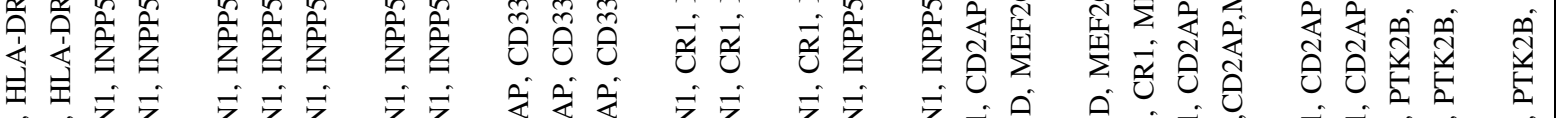

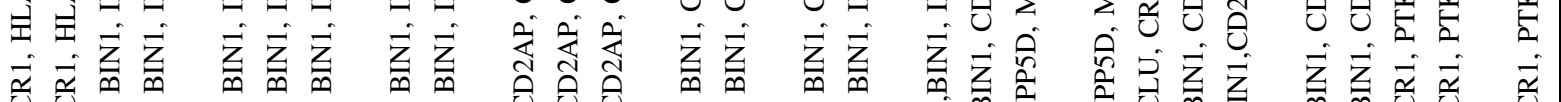

可

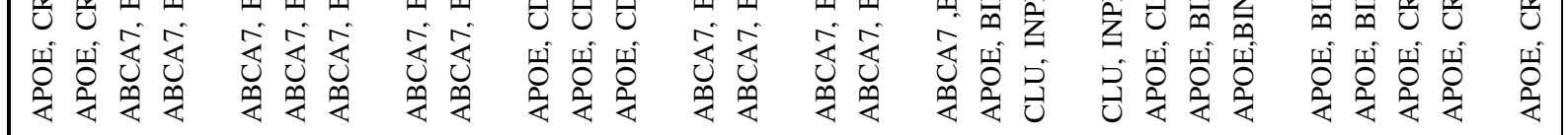

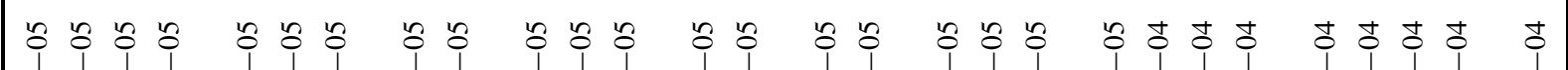

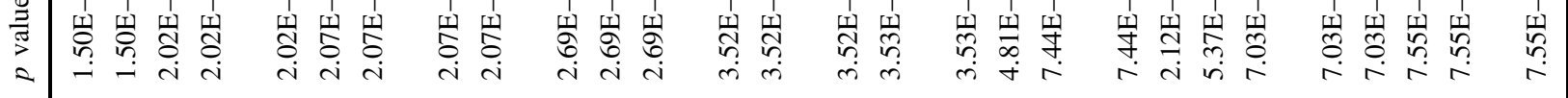

:

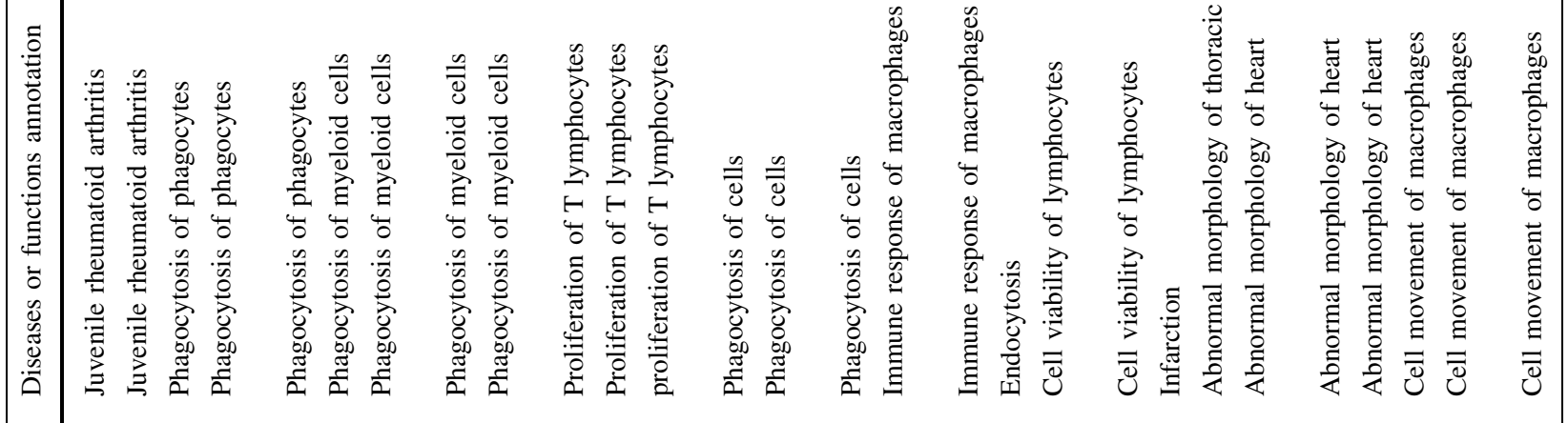

黄量

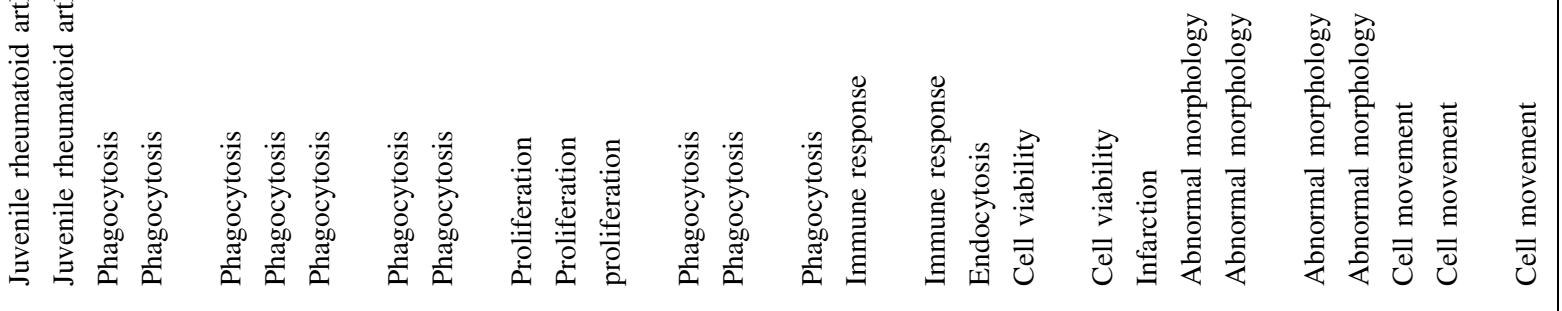

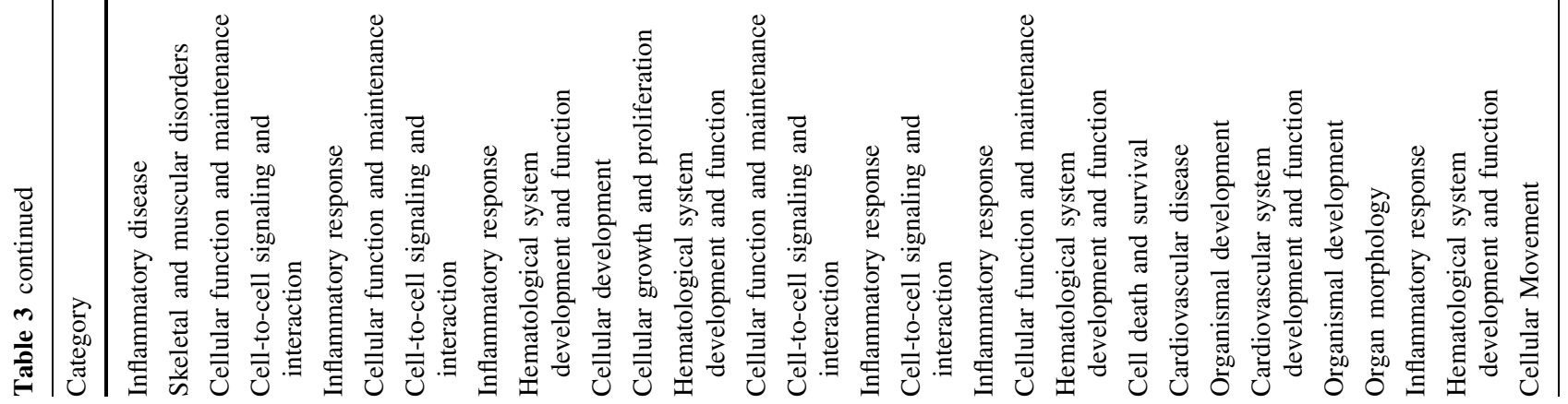


敢

$\sum_{i=1}^{2} \quad$ in

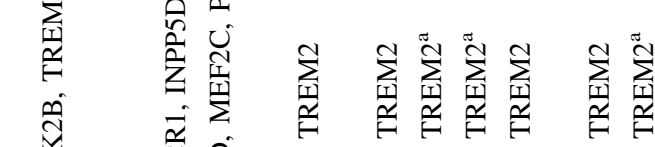

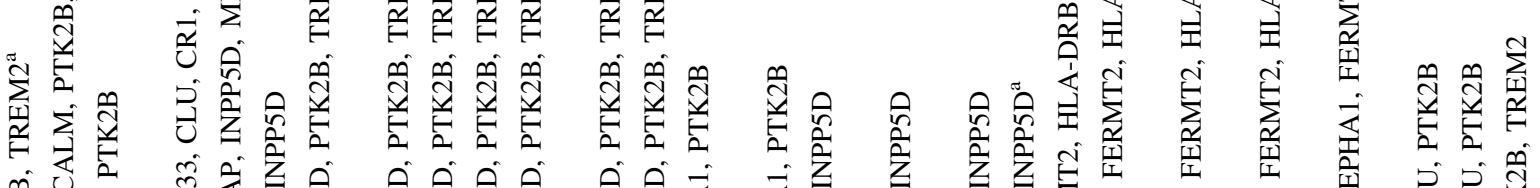

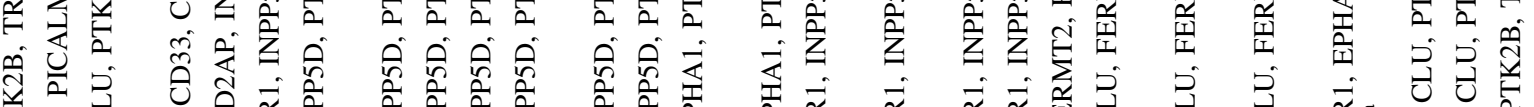

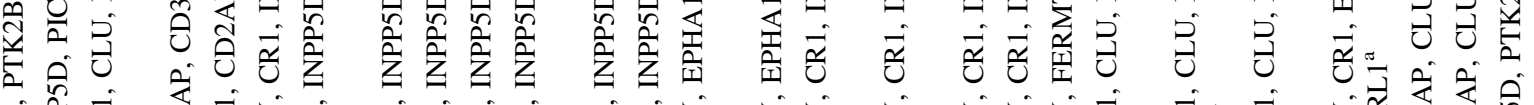

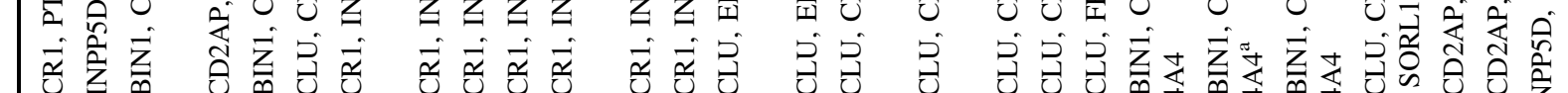

$\stackrel{\varrho}{=}$

离

宸

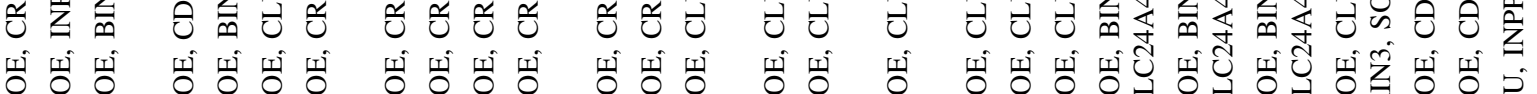

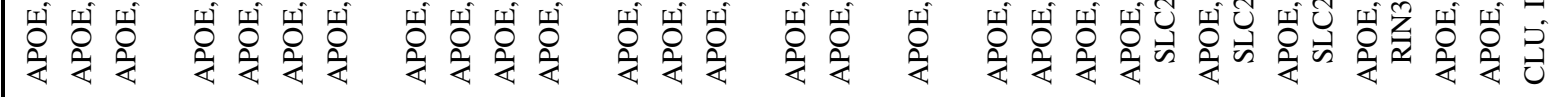

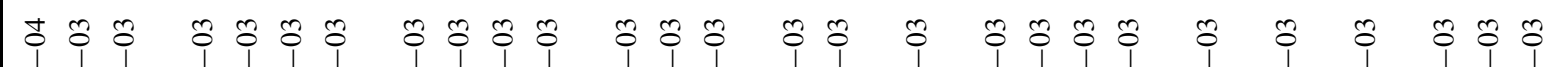

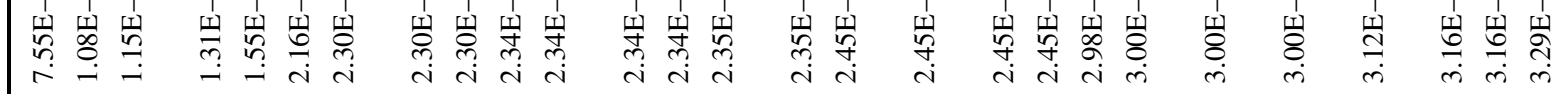

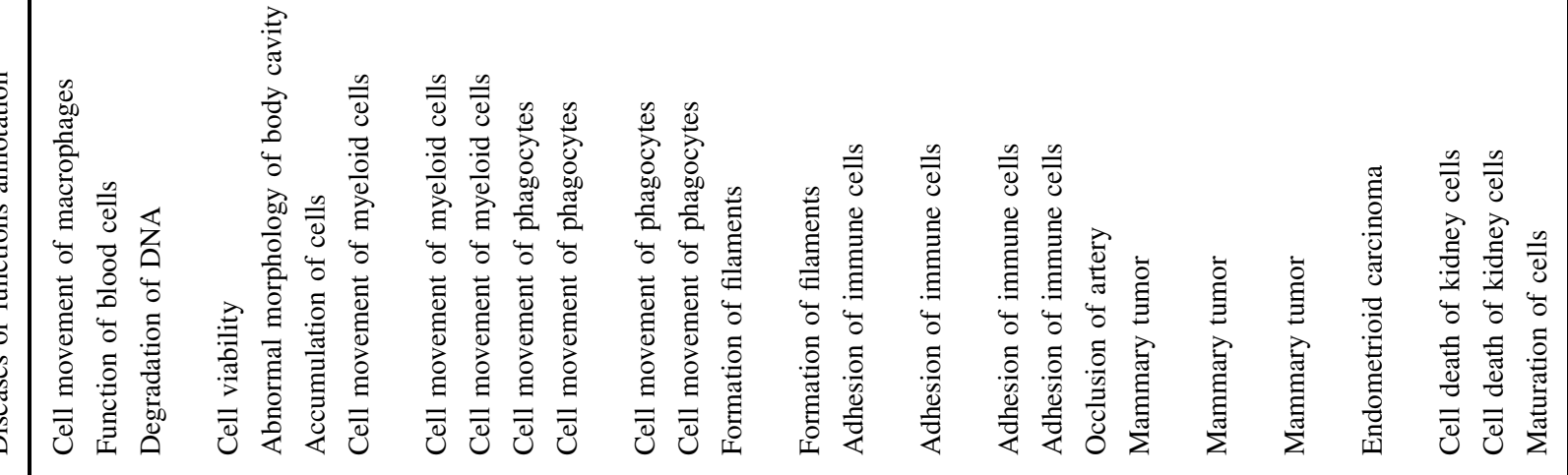

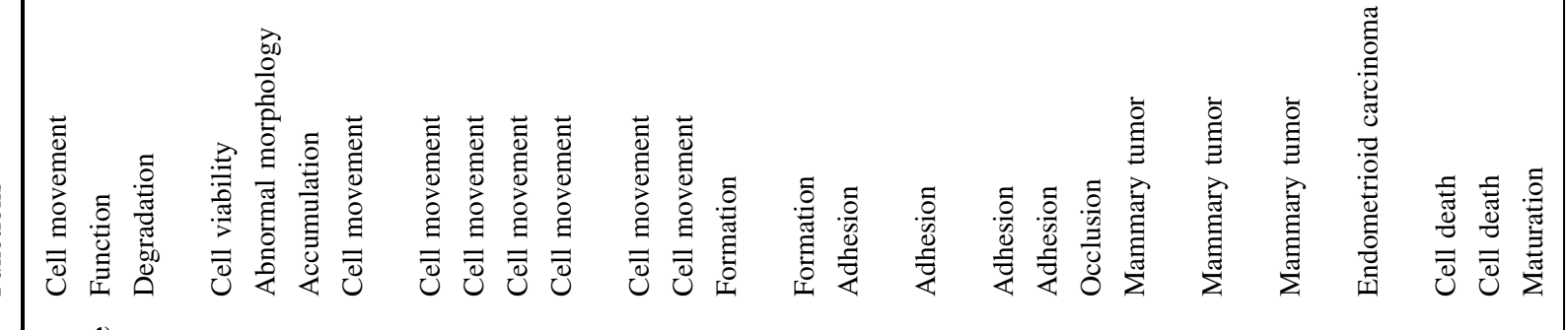

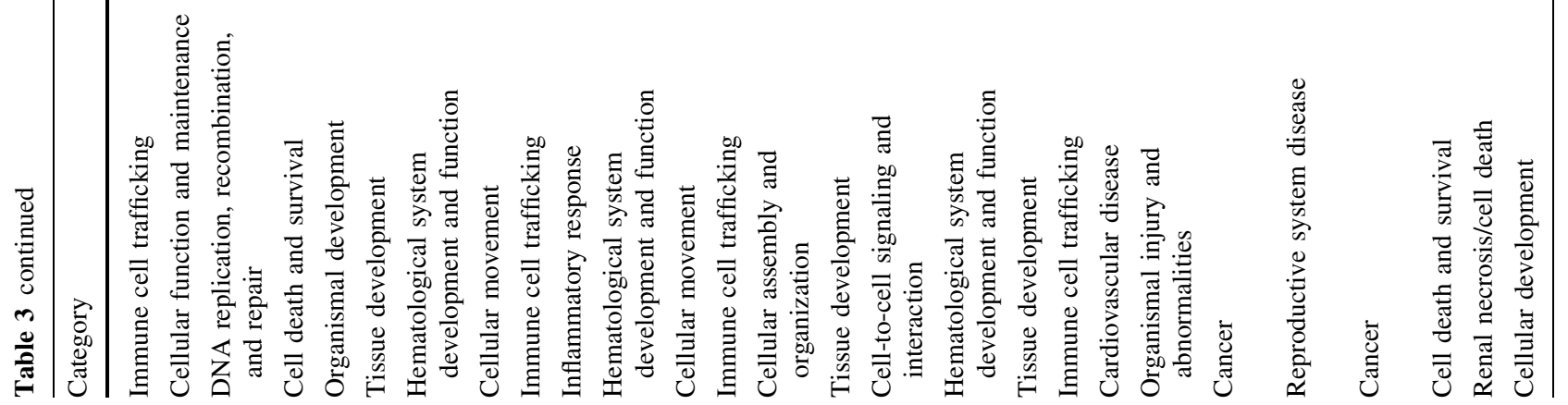




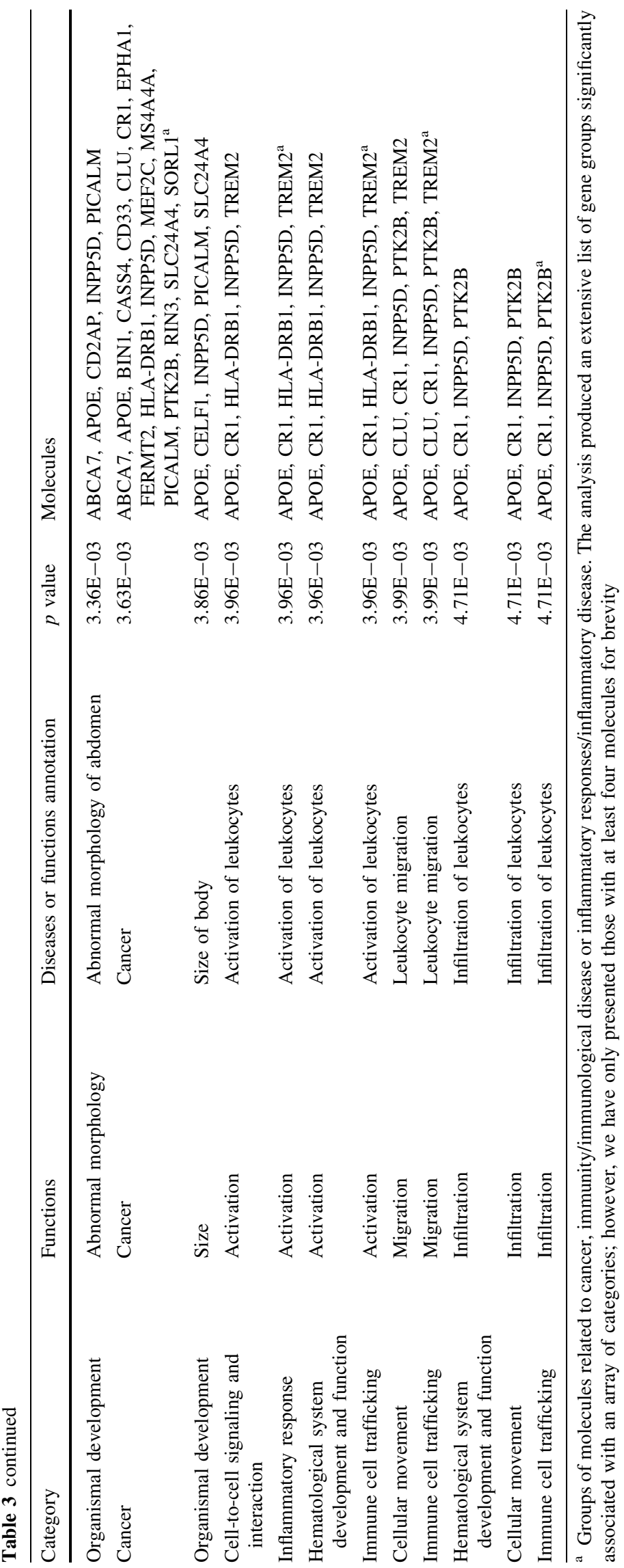


Acknowledgments The study was supported in part by NIH grants AG041718, AG030653 and AG005133.

Disclosure SL Rosenthal and MI Kamboh declare no conflicts of interest.

Human and Animal Rights and Informed Consent This article does not contain any studies with human or animal subjects performed by any of the author.

Open Access This article is distributed under the terms of the Creative Commons Attribution License which permits any use, distribution, and reproduction in any medium, provided the original author(s) and the source are credited.

\section{References}

Papers of particular interest, published recently, have been highlighted as:

- Of importance

-• Of major importance

1. Goate AM, Chartier-Harlin M-C, Mullan MC, Brown J, Crawford F, Fidani L, Giuffra L, Haynes A, Irving N, James L, et al. Segregation of a missense mutation in the amyloid precursor protein gene with familial Alzheimer's disease. Nature. 1991;349:704-6.

2. Sherrington R, Rogaev EI, Liang Y, Rogaeva EA, Levesque G, Ikeda M, Chi H, Lin C, Li G, Holman K, et al. Cloning of a gene bearing missense mutations in early-onset familial Alzheimer's disease. Nature. 1995;375:754-60.

3. Rogaev EI, Sherrington R, Rogaeva EA, Levesque G, Ikeda M, Liang Y, Chi H, Lin C, Holman K, Tsuda T, et al. Familial Alzheimer's disease in kindreds with missense mutations in a gene on chromosome 1 related to the Alzheimer's disease type 3 gene. Nature. 1995;376:775-8.

4. Levy-Lahad E, Wasco W, Poorkaj P, Romano DM, Oshima J, Pettingell WH, Yu CE, Jondro PD, Schmidt SD, Wang K, et al. Candidate gene for the chromosome 1 familial Alzheimer's disease locus. Science. 1995;269:973-7.

5. Gatz M, Reynolds CA, Fratiglioni L, Johansson B, Mortimer JA, Berg S, Fiske A, Pedersen NL. Role of genes and environments for explaining Alzheimer disease. Arch Gen Psychiatry. 2006;63:168-74.

6. - Lambert JC, Heath S, Even G, Campion D, Sleegers K, Hiltunen M, Combarros O, Zelenika D, Bullido MJ, Tavernier B, et al. Genomewide association study identifies vari-ants at CLU and CR1 associated with Alzheim-er's disease. Nat Genet. 2009;41:1094-9. This is one of two original LOAD genome-wide association studies identifying novel variations in CLU and CR1 for LOAD risk.

7. - Harold D, Abraham R, Hollingworth P, Sims R, Gerrish A, Hamshere ML, Pahwa JS, Moskvina V, Dowzell K, Williams A, et al. Genome-wide association study identifies variants at CLU and PICALM associated with Alzheimer's disease. Nat Genet. 2009;41:1088-93. This is one of two original LOAD genomewide association studies identifying novel variations in CLU and PICALM for LOAD risk.

8. - Seshadri S, Fitzpatrick AL, Ikram MA, DeStefano AL, Gudnason V, Boada M, Bis JC, Smith AV, Carassquillo MM, Lambert JC, et al. Genome-wide association analysis of genetic loci associated with Alzheimer disease. JAMA. 2010; 303:1832-40. This LOAD genome-wide association study was the first to find variations in BIN1 and EPHA1 associated with LOAD risk.
9. - Naj AC, Jun G, Beecham GW, Wang LS, Vardarajan BN, Buros J, Gallins PJ, Buxbaum JD, Jarvik GP, Crane PK, et al. Common variants at MS4A4/MS4A6E, CD2AP, CD33 and EPHA1 are associated with late-onset Alzheimer's disease. Nat Genet. 2011; 43:436-41. This is one of two LOAD genome-wide association studies identifying novel variations in MS4A4/ MS4A6E, CD2AP, and CD33 associated with LOAD risk.

10. - Hollingworth P, Harold D, Sims R, Gerrish A, Lambert JC, Carrasquillo MM, Abraham R, Hamshere ML, Pahwa JS, Moskvina V, et al. Com-mon variants at ABCA7, MS4A6A/ MS4A4E, EPHA1, CD33 and CD2AP are associated with Alzheimer's disease. Nat Genet. 2011 May; 43:429-35. This is one of two LOAD genome-wide association studies identifying novel variations in MS4A4/MS4A6E, CD2AP, and CD33 associated with LOAD risk.

11. • Lambert JC, Ibrahim-Verbaas CA, Harold D, Naj AC, Sims R, Bellenguez C, Jun G, Destefano AL, Bis JC, Beecham GW, et al. Meta-analysis of 74,046 individuals identifies 11 new susceptibility loci for Alzheimer's disease. Nat Genet. 2013; 45:1452-8. This GWAS meta-analysis identified 11 new loci that are significantly associated with the risk of LOAD, bringing the total number of genes found using GWAS approaches to 21 .

12. - Jonsson T, Atwal JK, Steinberg S, Snaedal J, Jonsson PV, Bjornsson S, Stefansson H, Sulem P, Gudbjartsson D, Maloney $\mathrm{J}$, et al. A mutation in APP protects against Alzheimer's disease and age-related cognitive decline. Nature. 2012; 488:96-9. This study used sequencing methods to determine a rare protective variant against $L O A D$ in an Icelandic population.

13. - Guerreiro R, Wojtas A, Bras J, Carrasquillo M, Rogaeva E, Majounie E, Cruchaga C, Sassi C, Kauwe JS, Younkin S, et al. TREM2 variants in Alzheimer's disease. N Engl J Med. 2013; 368:117-27. This paper is one of two studies identifying a novel association between a rare variant in TREM2 and increased risk of LOAD. Participants in this study are of European descent.

14. - Jonsson T, Stefansson H, Steinberg S, Jonsdottir I, Jonsson PV, Snaedal J, Bjornsson S, Huttenlocher J, Levey AI, Lah JJ, et al. N Engl J Med. 2013; 368:107-16. This paper is one of two studies identifying a novel association between a rare variant in TREM2 and increased risk of LOAD. Participants in this study are members of the Icelandic population.

15. - Cruchaga C, Karch CM, Jin SC, Benitez BA, Cai Y, Guerreiro R, Harari O, Norton J, Budde J, Bertelsen S, et al. Rare coding variants in the phospholipase D3 gene confer risk for Alzheimer's disease. Nature. 2014; 505:550-4. Identification of a novel association between PLD3 and increased risk of LOAD using sequencing methods.

16. Liu CC, Kanekiyo T, Xu H, Bu G. Apolipoprotein E and Alzheimer disease: risk, mechanisms and therapy. Nat Rev Neurol. 2013;9:106-18.

17. Nelson PT, Pious NM, Jicha GA, Wilcock DM, Fardo DW, Estus S, Rebeck GW. APOE- $\varepsilon 2$ and APOE- $\varepsilon 4$ correlate with increased amyloid accumulation in cerebral vasculature. J Neuropathol Exp Neurol. 2013;72:708-15.

18. Dunkelberger JR, Song WC. Complement and its role in innate and adaptive immune responses. Cell Res. 2010;20:34-50.

19. Zipfel PF, Skerka C. Complement regulators and inhibitory proteins. Nat Rev Immunol. 2009;9:729-40.

20. Brouwers N, Van Cauwenberghe C, Engelborghs S, Lambert JC, Bettens K, Le Bastard N, Pasquier F, Montoya AG, Peeters K, Mattheijssens M, et al. Alzheimer risk associated with a copy number variation in the complement receptor 1 increasing $\mathrm{C} 3 \mathrm{~b} /$ C4b binding sites. Mol Psychiatr. 2012;17:223-33.

21. Chibnik LB, Shulman JM, Leurgans SE, Schneider JA, Wilson RS, Tran D, Aubin C, Buchman AS, Heward CB, Myers AJ, et al. CR1 is associated with amyloid plaque burden and agerelated cognitive decline. Ann Neurol. 2011;69:560-9. 
22. Holton P, Ryten M, Nalls M, Trabzuni D, Weale ME, Hernandez D, Crehan H, Gibbs JR, Mayeux R, Haines JL, et al. Initial assessment of the pathogenic mechanisms of the recently identified Alzheimer risk Loci. Ann Hum Genet. 2013;77:85-105.

23. Barral S, Bird T, Goate A, Farlow MR, Diaz-Arrastia R, Bennett DA, Graff-Radford N, Boeve BF, Sweet RA, Stern Y, et al. Genotype patterns at PICALM, CR1, BIN1, CLU, and APOE genes are associated with episodic memory. Neurology. 2012;78: 1464-71.

24. Pan K, Liang XT, Zhang HK, Zhao JJ, Wang DD, Li JJ, Lian Q, Chang AE, Li Q, Xia JC. Characterization of bridging integrator 1 (BIN1) as a potential tumor suppressor and prognostic marker in hepatocellular carcinoma. Mol Med. 2012;18:507-18.

25. Ge K, DuHadaway J, Du W, Herlyn M, Rodeck U, Prendergast GC. Mechanism for elimination of a tumor suppressor: aberrant splicing of a brain-specific exon causes loss of function of Bin1 in melanoma. Proc Natl Acad Sci USA. 1999;96:9689-94.

26. Huang H, Colella S, Kurrer M, Yonekawa Y, Kleihues P, Ohgaki H. Gene expression profiling of low-grade diffuse astrocytomas by cDNA arrays. Cancer Res. 2000;60:6868-74.

27. Ghaneie A, Zemba-Palko V, Itoh H, Itoh K, Sakamuro D, Nakamura S, Soler AP, Prendergast GC. Bin1 attenuation in breast cancer is correlated to nodal metastasis and reduced survival. Cancer Biol Ther. 2007;6:192-4.

28. Pant S, Sharma M, Patel K, Caplan S, Carr CM, Grant BD. AMPH-1/Amphiphysin/Bin1 functions with RME-1/Ehd1 in endocytic recycling. Nat Cell Biol. 2009;11:1399-410.

29. Glennon EB, Whitehouse IJ, Miners JS, Kehoe PG, Love S, Kellett KA, Hooper NM. BIN1 Is decreased in sporadic but not familial Alzheimer's disease or in aging. PLoS One. 2013;8:e78806.

30. Chapuis J, Hansmannel F, Gistelinck M, Mounier A, Van Cauwenberghe C, Kolen KV, Geller F, Sottejeau Y, Harold D, Dourlen P, et al. Increased expression of BIN1 mediates Alzheimer genetic risk by modulating tau pathology. Mol Psychiatr. 2013;18:1225-34.

31. Tan L, Yu JT, Zhang W, Wu ZC, Zhang Q, Liu QY, Wang W, Wang HF, Ma XY, Cui WZ. Association of GWAS-linked loci with late-onset Alzheimer's disease in a northern Han Chinese population. Alzheimers Dement. 2013;9:546-53.

32. Metzner A, Precht C, Fehse B, Fiedler W, Stocking C, Günther A, Mayr GW, Jücker M. Reduced proliferation of CD34(+) cells from patients with acute myeloid leukemia after gene transfer of INPP5D. Gene Ther. 2009;16:570-3.

33. Leung WH, Tarasenko T, Bolland S. Differential roles for the inositol phosphatase SHIP in the regulation of macrophages and lymphocytes. Immunol Res. 2009;43:243-51.

34. Tiacci E, Döring C, Brune V, van Noesel CJ, Klapper W, Mechtersheimer G, Falini B, Küppers R, Hansmann ML. Analyzing primary Hodgkin and Reed-Sternberg cells to capture the molecular and cellular pathogenesis of classical Hodgkin lymphoma. Blood. 2012;120:4609-20.

35. Jickling GC, Ander BP, Stamova B, Zhan X, Liu D, Rothstein L, Verro P, Khoury J, Jauch EC, Pancioli AM, et al. RNA in blood is altered prior to hemorrhagic transformation in ischemic stroke. Ann Neurol. 2013;74:232-40.

36. Bao M, Hanabuchi S, Facchinetti V, Du Q, Bover L, Plumas J, Chaperot L, Cao W, Qin J, Sun SC, et al. CD2AP/SHIP1 complex positively regulates plasmacytoid dendritic cell receptor signaling by inhibiting the E3 ubiquitin ligase Cbl. J Immunol. 2012;189:786-92.

37. Bienvenu T, Diebold B, Chelly J, Isidor B. Refining the phenotype associated with MEF2C point mutations. Neurogenetics. 2013;14:71-5.

38. Le Meur N, Holder-Espinasse M, Jaillard S, Goldenberg A, Joriot S, Amati-Bonneau P, Guichet A, Barth M, Charollais A, Journel $\mathrm{H}$, et al. MEF2C haploinsufficiency caused by either microdeletion of the $5 \mathrm{q} 14.3$ region or mutation is responsible for severe mental retardation with stereotypic movements, epilepsy and/or cerebral malformations. J Med Genet. 2010;47:22-9.

39. Sakai Y, Ohkubo K, Matsushita Y, Akamine S, Ishizaki Y, Torisu H, Ihara K, Sanefuji M, Kim MS, Lee KU, et al. Neuroendocrine phenotypes in a boy with $5 \mathrm{q} 14$ deletion syndrome implicate the regulatory roles of myocyte-specific enhancer factor $2 \mathrm{C}$ in the postnatal hypothalamus. Eur J Med Genet. 2013;56:475-83.

40. Sivachenko A, Li Y, Abruzzi KC, Rosbash M. The transcription factor Mef2 links the Drosophila core clock to Fas2, neuronal morphology, and circadian behavior. Neuron. 2013;79:281-92.

41. Coogan AN, Schutová B, Husung S, Furczyk K, Baune BT, Kropp P, Häßler F, Thome J. The circadian system in Alzheimer's disease: disturbances, mechanisms, and opportunities. Biol Psychiatr. 2013;74:333-9.

42. Dustin ML, Olszowy MW, Holdorf AD, Li J, Bromley S, Desai N, Widder P, Rosenberger F, van der Merwe PA, Allen PM, et al. A novel adaptor protein orchestrates receptor patterning and cytoskeletal polarity in T-cell contacts. Cell. 1998;94:667-77.

43. Lynch DK, Winata SC, Lyons RJ, Hughes WE, Lehrbach GM, Wasinger V, Corthals G, Cordwell S, Daly RJ. A CortactinCD2-associated protein (CD2AP) complex provides a novel link between epidermal growth factor receptor endocytosis and the actin cytoskeleton. J Biol Chem. 2003;278:21805-13.

44. Shulman JM, Chen K, Keenan BT, Chibnik LB, Fleisher A, Thiyyagura P, Roontiva A, McCabe C, Patsopoulos NA, Corneveaux JJ, et al. Genetic susceptibility for Alzheimer disease neuritic plaque pathology. JAMA Neurol. 2013;70:1150-7.

45. Treusch S, Hamamichi S, Goodman JL, Matlack KE, Chung CY, Baru V, Shulman JM, Parrado A, Bevis BJ, Valastyan JS, et al. Functional links between $A \beta$ toxicity, endocytic trafficking, and Alzheimer's disease risk factors in yeast. Science. 2011;334:1241-5.

46. Shulman JM, Imboywa S, Giagtzoglou N, Powers MP, Hu Y, Devenport D, Chipendo P, Chibnik LB, Diamond A, Perrimon $\mathrm{N}$, et al. Functional screening in Drosophila identifies Alzheimer's disease susceptibility genes and implicates Tau-mediated mechanisms. Hum Mol Genet. 2014;23:870-7.

47. Trowsdale J, Knight JC. Major histocompatibility complex genomics and human disease. Annu Rev Genomics Hum Genet. 2013;14:301-23.

48. International Multiple Sclerosis Genetics Consortium, Wellcome Trust Case Control Consortium 2, Sawcer S, Hellenthal G, Pirinen M, Spencer CC, Patsopoulos NA, Moutsianas L, Dilthey A, Su Z, et al. Genetic risk and a primary role for cell-mediated immune mechanisms in multiple sclerosis. Nature. 2011;476:214-9.

49. Saiki M, Baker A, Williams-Gray CH, Foltynie T, Goodman RS, Taylor CJ, Compston DA, Barker RA, Sawcer SJ, Goris A. Association of the human leucocyte antigen region with susceptibility to Parkinson's disease. J Neurol Neurosurg Psychiatr. 2010;81:890-1.

50. International Parkinson Disease Genomics Consortium, Nalls MA, Plagnol V, Hernandez DG, Sharma M, Sheerin UM, Saad M, Simón-Sánchez J, Schulte C, Lesage S, et al. Imputation of sequence variants for identification of genetic risks for Parkinson's disease: a meta-analysis of genome-wide association studies. Lancet. 2011;377:641-9.

51. Harms AS, Cao S, Rowse AL, Thome AD, Li X, Mangieri LR, Cron RQ, Shacka JJ, Raman C, Standaert DG. MHCII is required for $\alpha$-synuclein-induced activation of microglia, CD4 T cell proliferation, and dopaminergic neurodegeneration. J Neurosci. 2013;33:9592-600.

52. Lai KO, Ip NY. Synapse development and plasticity: roles of ephrin/ Eph receptor signaling. Curr Opin Neurobiol. 2009;19:275-83.

53. Sharfe N, Nikolic M, Cimpeon L, Van De Kratts A, Freywald A, Roifman CM. EphA and ephrin-A proteins regulate integrin- 
mediated T lymphocyte interactions. Mol Immunol. 2008;45: 1208-20.

54. Ivanov AI, Romanovsky AA. Putative dual role of ephrin-Eph receptor interactions in inflammation. UBMB Life. 2006;58:389-94.

55. Hughes TM, Lopez OL, Evans RW, Kamboh MI, Williamson JD, Klunk WE, Mathis CA, Price JC, Cohen AD, Snitz BE, et al. Markers of cholesterol transport are associated with amyloid deposition in the brain. Neurobiol Aging. 2014;35:802-7.

56. Herath NI, Spanevello MD, Sabesan S, Newton T, Cummings M, Duffy S, Lincoln D, Boyle G, Parsons PG, Boyd AW. Overexpression of Eph and ephrin genes in advanced ovarian cancer: ephrin gene expression correlates with shortened survival. BMC Cancer. 2006;6:144.

57. Duriez B, Duquesnoy P, Escudier E, Bridoux AM, Escalier D, Rayet I, Marcos E, Vojtek AM, Bercher JF, Amselem S. A common variant in combination with a nonsense mutation in a member of the thioredoxin family causes primary ciliary dyskinesia. Proc Natl Acad Sci USA. 2007;104:3336-41.

58. Yerges-Armstrong L, Yau M, Liu Y, Krishnan S, Renner J, Eaton C, Kwoh C, Nevitt M, Duggan D, Mitchell B, et al. Association analysis of BMD-associated SNPs with knee osteoarthritis. J Bone Miner Res. 2013. doi:10.1002/jbmr.2160.

59. Shi D, Nakamura T, Nakajima M, Dai J, Qin J, Ni H, Xu Y, Yao $\mathrm{C}$, Wei J, Liu B, et al. Association of single-nucleotide polymorphisms in RHOB and TXNDC3 with knee osteoarthritis susceptibility: two case-control studies in East Asian populations and a meta-analysis. Arthritis Res Ther. 2008;10:R54.

60. Smith TB, Baker MA, Connaughton HS, Habenicht U, Aitken RJ. Functional deletion of Txndc 2 and Txndc 3 increases the susceptibility of spermatozoa to age-related oxidative stress. Free Radic Biol Med. 2013;65:872-81.

61. Escudier E, Duquesnoy P, Papon JF, Amselem S. Ciliary defects and genetics of primary ciliary dyskinesia. Paediatr Respir Rev. 2009;10:51-4.

62. He F, Umehara T, Saito K, Harada T, Watanabe S, Yabuki T, Kigawa T, Takahashi M, Kuwasako K, Tsuda K, et al. Structural insight into the zinc finger $\mathrm{CW}$ domain as a histone modification reader. Structure. 2010;18:1127-39.

63. Zlokovic BV. Cerebrovascular transport of Alzheimer's amyloid beta and apolipoproteins $\mathrm{J}$ and $\mathrm{E}$ : possible anti-amyloidogenic role of the blood-brain barrier. Life Sci. 1996;59:1483-97.

64. Nuutinen T, Suuronen T, Kauppinen A, Salminen A. Clusterin: a forgotten player in Alzheimer's disease. Brain Res Rev. 2009; 61:89-104.

65. Oda T, Pasinetti GM, Osterburg HH, Anderson C, Johnson SA, Finch CE. Purification and characterization of brain clusterin. Biochem Biophys Res Commun. 1994;204:1131-6.

66. May PC, Lampert-Etchells M, Johnson SA, Poirier J, Masters JN, Finch CE. Dynamics of gene expression for a hippocampal glycoprotein elevated in Alzheimer's disease and in response to experimental lesions in rat. Neuron. 1990;5:831-9.

67. Schrijvers EM, Koudstaal PJ, Hofman A, Breteler MM. Plasma clusterin and the risk of Alzheimer disease. JAMA. 2011;305: 1322-6.

68. Thambisetty M, Simmons A, Velayudhan L, Hye A, Campbell J, Zhang Y, Wahlund LO, Westman E, Kinsey A, Güntert A, et al. Association of plasma clusterin concentration with severity, pathology, and progression in Alzheimer disease. Arch Gen Psychiatr. 2010;67:739-48.

69. Ling IF, Bhongsatiern J, Simpson JF, Fardo DW, Estus S. Genetics of clusterin isoform expression and Alzheimer's disease risk. PLoS One. 2012;7:e33923.

70. Allen M, Zou F, Chai HS, Younkin CS, Crook J, Pankratz VS, Carrasquillo MM, Rowley CN, Nair AA, Middha S, et al. Novel late-onset Alzheimer disease loci variants associate with brain gene expression. Neurology. 2012;79:221-8.
71. Panico F, Casali C, Rossi G, Rizzi F, Morandi U, Bettuzzi S, Davalli P, Corbetta L, Storelli ES, Corti A, et al. Prognostic role of clusterin in resected adenocarcinomas of the lung. Lung Cancer. 2013;79:294-9.

72. Hassan MK, Watari H, Christenson L, Bettuzzi S, Sakuragi N. Intracellular clusterin negatively regulates ovarian chemoresistance: compromised expression sensitizes ovarian cancer cells to paclitaxel. Tumour Biol. 2011;32:1031-47.

73. Xiu P, Dong X, Dong X, Xu Z, Zhu H, Liu F, Wei Z, Zhai B, Kanwar JR, Jiang H, et al. Secretory clusterin contributes to oxaliplatin resistance by activating Akt pathway in hepatocellular carcinoma. Cancer Sci. 2013;104:375-82.

74. Giannakopoulos P, Kövari E, French LE, Viard I, Hof PR, Bouras C. Possible neuroprotective role of clusterin in Alzheimer's disease: a quantitative immunocytochemical study. Acta Neuropathol. 1998;95:387-94.

75. Kamboh MI, Demirci FY, Wang X, Minster RL, Carrasquillo MM, Pankratz VS, Younkin SG, Saykin AJ, Jun G, Baldwin C, et al. Genome-wide association study of Alzheimer's disease. Transl Psychiatr. 2012;2:e117.

76. Lev S, Moreno H, Martinez R, Canoll P, Peles E, Musacchio JM, Plowman GD, Rudy B, Schlessinger J. Protein tyrosine kinase PYK2 involved in $\mathrm{Ca}(2+)$-induced regulation of ion channel and MAP kinase functions. Nature. 1995;376:737-45.

77. Avraham H, Park SY, Schinkmann K, Avraham S. RAFTK/ Pyk2-mediated cellular signalling. Cell Signal. 2000;12:123-33.

78. Bojarski L, Herms J, Kuznicki J. Calcium dysregulation in Alzheimer's disease. Neurochem Int. 2008;52:621-33.

79. Heidinger V, Manzerra P, Wang XQ, Strasser U, Yu SP, Choi DW, Behrens MM. Metabotropic glutamate receptor 1-induced upregulation of NMDA receptor current: mediation through the Pyk2/Src-family kinase pathway in cortical neurons. J Neurosci. 2002;22:5452-61.

80. Dikic I, Tokiwa G, Lev S, Courtneidge SA, Schlessinger J. A role for Pyk2 and Src in linking G-protein-coupled receptors with MAP kinase activation. Nature. 1996;383:547-50.

81. Le HT, Maksumova L, Wang J, Pallen CJ. Reduced NMDA receptor tyrosine phosphorylation in PTPalpha-deficient mouse synaptosomes is accompanied by inhibition of four src family kinases and Pyk2: an upstream role for PTPalpha in NMDA receptor regulation. J Neurochem. 2006;98:1798-809.

82. Ishibashi K, Suzuki M, Sasaki S, Imai M. Identification of a new multigene four-transmembrane family (MS4A) related to CD20, $\mathrm{HTm} 4$ and beta subunit of the high-affinity IgE receptor. Gene. 2001;264:87-93.

83. Liang Y, Tedder TF. Identification of a CD20-, FcepsilonRIbeta-, and HTm4-related gene family: sixteen new MS4A family members expressed in human and mouse. Genomics. 2001;72: 119-27.

84. Kutok JL, Yang X, Folkerth RD, Imitola J, Raddassi K, Yano Y, Salahuddin S, Lawitts J, Imboden H, Chinami M, et al. The cell cycle associated protein, HTm4, is expressed in differentiating cells of the hematopoietic and central nervous system in mice. J Mol Histol. 2005;36:77-87.

85. Karch CM, Jeng AT, Nowotny P, Cady J, Cruchaga C, Goate AM. Expression of novel Alzheimer's disease risk genes in control and Alzheimer's disease brains. PLoS One. 2012;7:e50976.

86. Ando K, Brion JP, Stygelbout V, Suain V, Authelet M, Dedecker R, Chanut A, Lacor P, Lavaur J, Sazdovitch V, et al. Clathrin adaptor CALM/PICALM is associated with neurofibrillary tangles and is cleaved in Alzheimer's brains. Acta Neuropathol. 2013;125:861-78.

87. Scherzer CR, Offe K, Gearing M, Rees HD, Fang G, Heilman CJ, Schaller C, Bujo H, Levey AI, Lah JJ. Loss of apolipoprotein E receptor LR11 in Alzheimer disease. Arch Neurol. 2004; 61:1200-5. 
88. Gao X, Liu M, Sun L, Qin B, Yu H, Yang Z, Qi R, Gao F. SORL1 genetic variants modulate risk of amnestic mild cognitive impairment in northern Han Chinese. Int J Neurosci. 2014; 124:296-301.

89. Glerup S, Lume M, Olsen D, Nyengaard JR, Vaegter CB, Gustafsen C, Christensen EI, Kjolby M, Hay-Schmidt A, Bender D, et al. SorLA controls neurotrophic activity by sorting of GDNF and its receptors GFR $\alpha 1$ and RET. Cell Rep. 2013;3:186-99.

90. Roberts R, Timchenko NA, Miller JW, Reddy S, Caskey CT, Swanson MS, Timchenko LT. Altered phosphorylation and intracellular distribution of a (CUG)n triplet repeat RNA-binding protein in patients with myotonic dystrophy and in myotonin protein kinase knockout mice. Proc Natl Acad Sci USA. 1997; 94:13221-6.

91. Kuyumcu-Martinez NM, Wang GS, Cooper TA. Increased steadystate levels of CUGBP1 in myotonic dystrophy 1 are due to PKCmediated hyperphosphorylation. Mol Cell. 2007;28:68-78.

92. Kim YK, Mandal M, Yadava RS, Paillard L, Mahadevan MS. Evaluating the effects of CELF1 deficiency in a mouse model of RNA toxicity. Hum Mol Genet. 2014;23:293-302.

93. Talwar S, Balasubramanian S, Sundaramurthy S, House R, Wilusz CJ, Kuppuswamy D, D’Silva N, Gillespie MB, Hill EG, Palanisamy V. Overexpression of RNA-binding protein CELF1 prevents apoptosis and destabilizes pro-apoptotic mRNAs in oral cancer cells. RNA Biol. 2013;10:277-86.

94. Sulem P, Gudbjartsson DF, Stacey SN, Helgason A, Rafnar T, Magnusson KP, Manolescu A, Karason A, Palsson A, Thorleifsson $\mathrm{G}$, et al. Genetic determinants of hair, eye and skin pigmentation in Europeans. Nat Genet. 2007;39:1443-52.

95. Han J, Kraft P, Nan H, Guo Q, Chen C, Qureshi A, Hankinson SE, Hu FB, Duffy DL, Zhao ZZ, et al. A genome-wide association study identifies novel alleles associated with hair color and skin pigmentation. PLoS Genet. 2008;4:e1000074.

96. Larsson M, Duffy DL, Zhu G, Liu JZ, Macgregor S, McRae AF, Wright MJ, Sturm RA, Mackey DA, Montgomery GW, et al. GWAS findings for human iris patterns: associations with variants in genes that influence normal neuronal pattern development. Am J Hum Genet. 2011;89:334-43.

97. Parry DA, Poulter JA, Logan CV, Brookes SJ, Jafri H, Ferguson $\mathrm{CH}$, Anwari BM, Rashid Y, Zhao H, Johnson CA, et al. Identification of mutations in SLC24A4, encoding a potassiumdependent sodium/calcium exchanger, as a cause of amelogenesis imperfecta. Am J Hum Genet. 2013;92:307-12.

98. Adeyemo A, Gerry N, Chen G, Herbert A, Doumatey A, Huang H, Zhou J, Lashley K, Chen Y, Christman M, et al. A genomewide association study of hypertension and blood pressure in African Americans. PLoS Genet. 2009;5:e1000564.

99. Zhao T, Guan L, Yu Y, Pei X, Zhan J, Han L, Tang Y, Li F, Fang W, Zhang $\mathrm{H}$. Kindlin-2 promotes genome instability in breast cancer cells. Cancer Lett. 2013;330:208-16.

100. Lai-Cheong JE, Ussar S, Arita K, Hart IR, McGrath JA. Colocalization of kindlin-1, kindlin-2, and migfilin at keratinocyte focal adhesion and relevance to the pathophysiology of Kindler syndrome. J Invest Dermatol. 2008;128:2156-65.

101. Pfrieger FW. Cholesterol homeostasis and function in neurons of the central nervous system. Cell Mol Life Sci. 2003;60: 1158-71.

102. Kim WS, Fitzgerald ML, Kang K, Okuhira K, Bell SA, Manning JJ, Koehn SL, Lu N, Moore KJ, Freeman MW. Abca7 null mice retain normal macrophage phosphatidylcholine and cholesterol efflux activity despite alterations in adipose mass and serum cholesterol levels. J Biol Chem. 2005;280:3989-95.

103. Kim WS, Guillemin GJ, Glaros EN, Lim CK, Garner B. Quantitation of ATP-binding cassette subfamily-A transporter gene expression in primary human brain cells. NeuroReport. 2006;17:891-6.
104. Kim WS, Li H, Ruberu K, Chan S, Elliott DA, Low JK, Cheng D, Karl T, Garner B. Deletion of Abca7 increases cerebral amyloid- $\beta$ accumulation in the J20 mouse model of Alzheimer's disease. J Neurosci. 2013;33:4387-94.

105. Chan SL, Kim WS, Kwok JB, Hill AF, Cappai R, Rye KA, Garner B. ATP-binding cassette transporter A7 regulates processing of amyloid precursor protein in vitro. $\mathrm{J}$ Neurochem. 2008;106:793-804.

106. Reitz C, Jun G, Naj A, Rajbhandary R, Vardarajan BN, Wang LS, Valladares O, Lin CF, Larson EB, Graff-Radford NR, et al. Variants in the ATP-binding cassette transporter (ABCA7), apolipoprotein $\mathrm{E} \varepsilon 4$, and the risk of late-onset Alzheimer disease in African Americans. JAMA. 2013;309:1483-92.

107. Tateno H, Li H, Schur MJ, Bovin N, Crocker PR, Wakarchuk WW, Paulson JC. Distinct endocytic mechanisms of CD22 (Siglec-2) and Siglec-F reflect roles in cell signaling and innate immunity. Mol Cell Biol. 2007;27:5699-710.

108. Griciuc A, Serrano-Pozo A, Parrado AR, Lesinski AN, Asselin CN, Mullin K, Hooli B, Choi SH, Hyman BT, Tanzi RE. Alzheimer's disease risk gene CD33 inhibits microglial uptake of amyloid beta. Neuron. 2013;78:631-43.

109. Bradshaw EM, Chibnik LB, Keenan BT, Ottoboni L, Raj T, Tang A, Rosenkrantz LL, Imboywa S, Lee M, Von Korff A, et al. CD33 Alzheimer's disease locus: altered monocyte function and amyloid biology. Nat Neurosci. 2013;16:848-50.

110. Tikhmyanova N, Little JL, Golemis EA. CAS proteins in normal and pathological cell growth control. Cell Mol Life Sci. 2010; 67:1025-48.

111. Singh MK, Dadke D, Nicolas E, Serebriiskii IG, Apostolou S, Canutescu A, Egleston BL, Golemis EA. A novel Cas family member, HEPL, regulates FAK and cell spreading. Mol Biol Cell. 2008;19:1627-36.

112. Tikhmyanova N, Tulin AV, Roegiers F, Golemis EA. Dcas supports cell polarization and cell-cell adhesion complexes in development. PLoS One. 2010;5:e12369.

113. Kirsch KH, Georgescu MM, Ishimaru S, Hanafusa H. CMS: an adapter molecule involved in cytoskeletal rearrangements. Proc Natl Acad Sci USA. 1999;96:6211-6.

114. Manolio TA, Collins FS, Cox NJ, Goldstein DB, Hindorff LA, Hunter DJ, McCarthy MI, Ramos EM, Cardon LR, Chakravarti A, et al. Finding the missing heritability of complex diseases. Nature. 2009;461:747-53.

115. Gibson G. Rare and common variants: twenty arguments. Nat Rev Genet. 2012;13:135-45.

116. Kero M, Paetau A, Polvikoski T, Tanskanen M, Sulkava R, Jansson L, Myllykangas L, Tienari PJ. Amyloid precursor protein (APP) A673T mutation in the elderly Finnish population. Neurobiol Aging. 2013;34:1518.e1-3.

117. Bamne MN, Demirci FY, Berman S, Snitz BE, Rosenthal SL, Wang X, Lopez O, Kamboh MI. Investigation of an APP protective mutation (A673T) in a North American case-control sample of late-onset Alzheimer's disease. Neurobiol Aging. 2014;. doi:10.1016/j.neurobiolaging.2014.01.020.

118. Liu YW, He YH, Zhang YX, Cai WW, Yang LQ, Xu LY, Kong QP. Absence of A673T variant in APP gene indicates an alternative protective mechanism contributing to longevity in Chinese individuals. Neurobiol Aging. 2014;35:935.e11-2.

119. Guerreiro R, Hardy J. TREM2 and neurodegenerative disease. N Engl J Med. 2013;369:1569-70.

120. Paloneva J, Manninen T, Christman G, Hovanes K, Mandelin J, Adolfsson R, Bianchin M, Bird T, Miranda R, Salmaggi A, et al. Mutations in two genes encoding different subunits of a receptor signaling complex result in an identical disease phenotype. Am J Hum Genet. 2002;71:656-62.

121. Soragna D, Papi L, Ratti MT, Sestini R, Tupler R, Montalbetti L. An Italian family affected by Nasu-Hakola disease with a 
novel genetic mutation in the TREM2 gene. J Neurol Neurosurg Psychiatr. 2003;74:825-6.

122. Paloneva J, Autti T, Raininko R, Partanen J, Salonen O, Puranen M, Hakola P, Haltia M. CNS manifestations of Nasu-Hakola disease: a frontal dementia with bone cysts. Neurology. 2001;56:1552-8.

123. Hsieh CL, Koike M, Spusta SC, Niemi EC, Yenari M, Nakamura MC, Seaman WE. A role for TREM2 ligands in the phagocytosis of apoptotic neuronal cells by microglia. J Neurochem. 2009;109:1144-56.

124. Zhang J, Chen S, Zhang S, Lu Z, Yang H, Wang H. Over-expression of phospholipase D3 inhibits Akt phosphorylation in C2C12 myoblasts. Sheng Wu Gong Cheng Xue Bao. 2009;25:1524-31.

125. Osisami M, Ali W, Frohman MA. A role for phospholipase D3 in myotube formation. PLoS One. 2012;7:e33341.
126. Strappazzon F, Torch S, Trioulier Y, Blot B, Sadoul R, Verna JM. Survival response-linked Pyk2 activation during potassium depletion-induced apoptosis of cerebellar granule neurons. Mol Cell Neurosci. 2007;34:355-65.

127. Walker LC, Waddell N, Ten Haaf A, Grimmond S, kConFab Investigators, Spurdle AB. Use of expression data and the CGEMS genome-wide breast cancer association study to identify genes that may modify risk in BRCA1/2 mutation carriers. Breast Cancer Res Treat. 2008;112:229-36.

128. Roe CM, Behrens MI, Xiong C, Miller JP, Morris JC. Alzheimer disease and cancer. Neurology. 2005;64:895-8.

129. Ganguli M. A reduced risk of Alzheimer's disease in those who survive cancer. BMJ. 2012;344:e1662. 